\title{
Presence Confirmation of Non-Native Species Pagrus major (Temminck And Schlegel, 1843) in the Eastern Mediterranean
}

\author{
Cladas Yannis ${ }^{1}$, Spala Kallia ${ }^{2}$, Doudoumis Vangelis ${ }^{1}$, Ketsilis-Rinis Vlasis ${ }^{2}$, Batargias Costas $^{1}$ and \\ Koutsikopoulos Constantin ${ }^{2}$
}

${ }^{1}$ Fisheries \& Aquaculture Technology Department, Technological Educational Institute of Western Greece, Greece

${ }^{2}$ Department of Biology, University of Patras, Greece

Submission: January 03, 2019; Published: February 04, 2019

Corresponding author: Yannis Cladas, Fisheries \& Aquaculture Technology Department, Technological Educational Institute of Western Greece, Nea Ktiria, 30200, Mesolonghi, Greece

Abstract

Four specimens of red seabream Pagrus major (non-native species), were caught at the entrance of Amvrakikos Gulf and Echinades islands of the Ionian Sea (Western Greece). Identification was confirmed by genetics. Location and morphological characteristics as well as stomach content analysis and a brief history of farming attempts in the Mediterranean are presented.

Keywords: Non-Native Species; Pagrus Major; East Mediterranean

\section{Introduction}

Red seabream Pagrus major [1], mentioned P. auratus major by Tabata and Taniguchi [2] as subspecies of $P$. auratus, is distributed in the Northwest Pacific: northeastern part of South China Sea (Philippines excluded) northward to Japan [3]. The species is farmed in Japan for over 60 years [4]. Except for its native range, this species has not been reported as naturalized in any other marine area of the world. Although the red sea bream Pagrus major successfully bred since 1985 sporadically or continuously in fish farms in Mediterranean, namely Croatia, Italy, Cyprus and Greece [5-8], there is only one reference concerning the catch of one individual in the field (2004, Island Molat - eastern middle Adriatic) [1]. The lack of additional relevant information on this subject is probably due to the difficulty of the macroscopic distinction of this species from the native species Pagrus pagrus. The color differences of the body, head and fins mentioned in the relevant identification keys $[9,10]$ are not easily identified by fishers and consumers.

\section{Matherial and Methods}

Four specimens of red sea bream Pagrus major were caught in the Ionian Sea from September 3 to November 1, 2018. The identification of these specimens as Pagrus major was initially based on the particular coloring of the caudal fins, black posterior margin, lower margin white [10] and it was confirmed by genetic analysis. Total genomic DNA was extracted from fin tissues using modified salting out procedure [11]. The DNA barcoding of the analyzed samples (sample codes 141, 144, 353 and 354) was based on the PCR amplification of the mtCOI gene marker using the universal primers FishF2/FishR2 [12]. The PCR products were purified by a PEG (Polyethylene glycol)-NaCl method [13]. Both strands were sequenced using the Big Dye Terminator v3.1 Cycle Sequencing Kit (PE Applied Biosystems) in a 3500 Genetic Analyzer (Applied Biosystems) and all retrieved sequences were manually edited with Geneious 7.1.2. Total length, weight, sex and stomach contents of the specimens were recorded.

\section{Results}

Fishing data and the main features of the caught fishes are given in Table 1 . Three of them were caught at the entrance of Amvrakikos Gulf and one, coded as 144, in Echinades islands (Ionian Sea). Eleven items were found in the stomach of this specimen, the composition of preys per animal group being $8 \%$ Brachyura (crab claws), 8\% Echinoidea, 42\% Chaetognatha, 25\% Bivalve, and one piece of sardine (8\%), possibly the long line bait (Table1). None of the captured specimens showed skeletal malformations, as confirmed also by X-Rays images. 
Table 1: Catch data and main characteristics of Pagrus major specimens caught in the Ionian Sea.

\begin{tabular}{|c|c|c|c|c|}
\hline Fish code number & 141 & 144 & 353 & 354 \\
\hline Fishing area & Amvrakikos Gulf & Echinades islands & Amvrakikos Gulf & Amvrakikos Gulf \\
\hline Date of catching & $30 / 9 / 2018$ & $7 / 10 / 2018$ & $30 / 10 / 2018$ & $1 / 11 / 2018$ \\
\hline Site coordinates & $38.934 \mathrm{~N}$ & $38.43-38.49 \mathrm{~N}$ & $38.928 \mathrm{~N} 20.743 \mathrm{E}$ & $38.943 \mathrm{~N} 20.741 \mathrm{E}$ \\
\hline Site deepth (m) & $20.737 \mathrm{E}$ & $21.01-21.07 \mathrm{E}$ & 3 \\
\hline Fishing gear & 6 & $?$ & Gill net & Gill net \\
\hline $\begin{array}{c}\text { Total length TL (cm), } \\
\text { Weight (g), Sex }\end{array}$ & $25.2,231, \sigma^{*}$ & Long-line & $24.4,209, \%$ & $24.3,225, \sigma^{*}$ \\
\hline Stomach contents & NO & YES & NO & NO \\
\hline
\end{tabular}

Regarding the verification of the species, based on the BLAST analysis of the datasets of the mtCOI gene, it seems that all analyzed samples were identical and more like the Pagrus major, thus the mtCOI sequences were identical with five P. major specimens (KU199070, KU199066, GU207340, FJ237862 and AP002949, with coverage $650 \mathrm{bp} / 650 \mathrm{bp}$ all of them). The history of the species in the area, the short sampling period of the study and its limited spatial range, suggest that a larger and more specific field study is necessary to evaluate the imprint of this non-native species in the Eastern Mediterranean.

\section{References}

1. Dulcic J and M Kraljevic (2007) On the record of red seabream Pagrus major (Temminck and Schlegel, 1843) (Osteichthyes: Sparidae) in the Adriatic Sea. Scientia Marina 71(1): 15-17.

2. Tabata K \& Taniguchi N (2000) Differences between Pagrus major and Pagrus auratus through mainly mtDNA control region analysis. Fisheries Science 66(1): 9-18.

3. Fishbase (2019) Computer generated distribution maps for Pagrus major (Red seabream), with modelled year 2100 native range map based on IPCC A2 emissions scenario.

4. Foscarini R (1988) A Review: Intensive Farming Procedure for Red Sea Bream (Pagrus major) in Japan. Aquaculture 72(3-4): 191-246.

5. Lisac D (1989) Pilot production of red sea bream (Pagrus major) in Yugoslavia - present status. In: De Pauw N (Ed.) Aquaculture: a biotechnology in progress, European Aquaculture Society, Belgium, pp. 217-221
6. Sweetman JW (1992) Larviculture of Mediterranean Marine Fish Species: Current Status and Future Trends. Journal of the World Aquaculture Society 23(4): 330-337.

7. Stephanou D (2000) Experience of offshore fish farming in Cyprus. In: Muir,J and Basurco, hano B (Eds) Mediterranean Offshore Mariculture. Based on the contents of the advanced course of CIHEAM network on technology of aquaculture in the Mediterranean (TECAM), Zaragoza, Spain, Centre international de hautes études agronomiques méditerranéenes, Paris

8. Cataudella S, Crosetti D (2011) Evolution of Italian aquaculture within the Mediterranean region. In: Cataudella S, Spagnolo M (eds) The state of Italian marine fisheries and aquaculture. Ministero delle Politiche Agricole, Alimentari e Forestali (MiPAAF), Rome (Italy), Pp. 620

9. Whitehead PJP, ML Bauchot, JC Hureau, J Nielsen and E. Tortonese (eds.), Fishes of the North-eastern Atlantic and the Mediterranean. UNESCO, Paris, Pp.1473

10. Nakabo T (2002) Fishes of Japan with pictorial keys to the species. In: English edition I, Tokai University Press, Japan, pp. 866

11. Miller SA, Dykes DD, and Polesky HF (1988) A simple procedure for extracting DNA from human nucleated cells. Nucleic Acids Res 16(3): 1215.

12. Ward RD, Zemlak TS, Innes BH, Last PR, Hebert PDN (2005) DNA barcoding Australia's fish species. Philos Trans R So Lon B Biol Sci 360(1462): 1847-1857.

13. Sambrook J, Fritsch EF, Maniatis T (1989) Molecular Cloning. In: (2nd edn). Cold Spring Harbor Laboratory Press, New York, Pp.1626

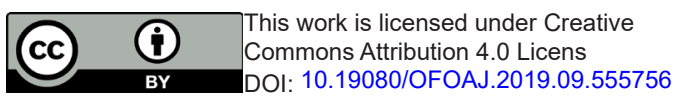

\begin{tabular}{|l|}
\hline \multicolumn{1}{|c|}{ Your next submission with Juniper Publishers } \\
will reach you the below assets \\
- Quality Editorial service \\
- Swift Peer Review \\
- Reprints availability \\
- E-prints Service \\
- Manuscript Podcast for convenient understanding \\
- Global attainment for your research \\
- Manuscript accessibility in different formats \\
( Pdf, E-pub, Full Text, Audio) \\
- Unceasing customer service \\
Track the below URL for one-step submission \\
https://juniperpublishers.com/online-submission.php \\
\hline
\end{tabular}

